TITLE:

\title{
Nasal delivery of Japanese cedar pollen Cryj1 by using self-gelling immunostimulatory DNA for effective induction of immune responses in mice.
}

\section{$\operatorname{AUTHOR}(\mathrm{S})$ :}

Ishii-Mizuno, Yumiko; Umeki, Yuka; Takahashi, Yuki; Kato, Yukinori; Takabayashi, Tetsuji; Fujieda, Shigeharu; Takakura, Yoshinobu; Nishikawa, Makiya

\section{CITATION:}

Ishii-Mizuno, Yumiko ...[et al]. Nasal delivery of Japanese cedar pollen Cryj1 by using selfgelling immunostimulatory DNA for effective induction of immune responses in mice. Journal of controlled release 2015, 200: 52-59

\section{ISSUE DATE:}

2015-02-28

URL:

http://hdl.handle.net/2433/193673

\section{RIGHT:}

C 2015 Elsevier B.V.; この論文は出版社版でありません。引用の際には 出版社版をご確認ご利用ください。; This is not the published version. Please cite only the published version. 


\section{Nasal delivery of Japanese cedar pollen Cryj1 by using self-gelling immunostimulatory DNA for effective induction of immune responses in mice}

\section{Yumiko Ishii-Mizuno, ${ }_{1}^{1}$ Yuka Umeki, ${ }^{1}$ Yuki Takahashi, ${ }^{1}$ Yukinori Kato, ${ }^{2}$ Tetsuji Takabayashi, ${ }^{2}$ Shigeharu Fujieda, ${ }^{2}$ Yoshinobu Takakura, ${ }^{1}$ and Makiya Nishikawa, ${ }^{1, *}$}

${ }^{1}$ Department of Biopharmaceutics and Drug Metabolism, Graduate School of Pharmaceutical Sciences, Kyoto University, Sakyo-ku, Kyoto 606-8501, Japan

${ }^{2}$ Division of Otorhinolaryngology Head \& Neck Surgery, Department of Sensory and Locomotor Medicine, Faculty of Medical Science, University of Fukui, Yoshida-gun, Fukui 910-1193

* Corresponding author:

Makiya Nishikawa, Ph.D., Department of Biopharmaceutics and Drug Metabolism, Graduate School of Pharmaceutical Sciences, Kyoto University, Sakyo-ku, Kyoto, 606-8501, Japan. Tel.: +81 75 7534580; fax: +81 75 7534614. E-mail address: makiya@pharm.kyoto-u.ac.jp 


\section{Abstract}

To develop an immunotherapeutic vaccine for treatment of allergic rhinitis, we developed a controlled release formulation of Cryj1, a major Japanese cedar pollen allergen, with immunostimulatory potency. Two sets of hexapod-like structured DNA (hexapodna) were prepared using six oligodeoxynucleotides (ODNs) each, including ODNs with an unmethylated cytosine-phosphate-guanine $(\mathrm{CpG})$ sequence (CpG motif), to obtain an immunostimulatory DNA hydrogel (sDNA hydrogel). A non-immunostimulatory DNA hydrogel (nsDNA hydrogel) was also prepared using ODNs with no CpG motifs. The sDNA hydrogel was more effective than its components or the nsDNA hydrogel for production of interleukin (IL)-12 after addition to murine macrophage-like RAW264.7 cells or after intranasal administration to mice. Then, a Cryj1-loaded sDNA hydrogel (Cryj1/sDNA hydrogel) formulation was prepared by mixing solutions containing both Cryj 1 and hexapodna. Cryj1 was slowly released from the sDNA hydrogel in phosphate-buffed saline. After intranasal administration of the fluorescein isothiocyanate (FITC)-labeled Cryj1/sDNA hydrogel in mice, FITC-Cryj1 was retained in the nasal cavity for a longer period than FITC-Cryj1 mixed with hexapodna in solution. Intranasal immunization of mice with the Cryj1/sDNA hydrogel resulted in high levels of Cryj1-specific IgG in nasal lavage fluid (NFL), IL-12 and interferon- $\gamma$ release from spleen cells after re-stimulation with Cryj1 when compared with intranasal immunization with the other formulations examined. These results indicate that the self-gelling immunostimulatory DNA hydrogel is an effective formulation for controlled induction of allergen-specific immune responses.

Keywords: hydrogel; $\mathrm{CpG}$ motif; controlled release; nasal delivery; allergen; self-gelling 


\section{Introduction}

Toll-like receptor 9 (TLR9) is the receptor for DNA containing the unmethylated cytosine-phosphate-guanine ( $\mathrm{CpG}$ ) sequence, or $\mathrm{CpG}$ motif (CpG DNA). Ligation of TLR9 results in the release of tumor necrosis factor (TNF)- $\alpha$, interleukin (IL)-12, and other proinflammatory cytokines, and in the stimulation of humoral and cellular immune responses [1-4]. CpG DNA-induced secretion of Th1 cytokines such as IL-12 and interferon (IFN)- $\gamma$ converts uncommitted T-cells (Th0) to T helper 1 cells (Th1), which suppress the function of Th2 cells [5]. At least two mechanisms for CpG DNA as an allergy vaccine adjuvant are known. The first is reduced Th2 responses manifested as reduced activation of basophils and eosinophils, and reduced class-switching of B-cells to produce IgE $[4, \mathbf{5}]$. The second is CpG DNA-induced humoral immunity such as competition of allergen-specific IgG and $\operatorname{IgA}$ with $\operatorname{IgE}$ for allergen binding [6, 7]. Previous clinical studies have shown that subcutaneous injection of $\mathrm{CpG}$ DNA conjugated with ragweed pollen antigen was effective for preventing ragweed seasonal allergic rhinitis in humans $[8,9]$.

In addition to its immunostimulatory activity, DNA possesses various drug-like characteristics, including high water solubility, ease of chemical synthesis on a large scale, and high stability and biodegradability [10]. DNA also can be used as a drug delivery system through conjugation with low-molecular-weight compounds or formation of hydrogels [11]. We previously reported that doxorubicin (DXR) intercalated into $\mathrm{CpG}$ motif-containing plasmid DNA was delivered to colon carcinoma cells in the mouse liver where it efficiently inhibited tumor growth [12]. We also reported that DXR loaded in CpG DNA hydrogels was gradually released and effectively inhibited the growth of subcutaneous tumors [13]. We extended these results and recently developed a novel method to prepare a ligase-free, self-gelling injectable DNA hydrogel. Intradermal injection of this CpG DNA hydrogel loaded with ovalbumin as a model antigen showed high potency and low toxicity as a vaccine adjuvant [14]. Because this self-gelling DNA hydrogel can be administered to cavities as a spray, it could be a useful delivery system for intranasal vaccines.

Allergic rhinitis is a global health problem affecting 10-20\% of the population [15]. The incidence of allergic rhinitis caused by Japanese cedar pollen (JCP) is estimated to be 30-40\% among adult Japanese population [16]. Although symptomatic therapy with pharmacological agents has been a common treatment for allergic rhinitis thus far, considerable attention has been paid to allergen-specific immunotherapies that induce long-term remission [17]. At present, allergy immunotherapy involves 3-5 years of subcutaneous injections, but a short-term and self-administrable mucosal immunotherapy such as intranasal or sublingual vaccines will be ideal for patients [18]. Immunotherapy with an immunostimulatory adjuvant such as CpG DNA is expected to induce effective immune responses for shorter mucosal immunotherapy.

To the best of our knowledge, this is the first report of a newly designed self-gelling immunostimulatory CpG DNA hydrogel loaded with Cryj1, a major JCP allergen (Cryj1/sDNA hydrogel). The physicochemical properties and biological activity of the Cryj1/sDNA hydrogel were examined after intranasal administration to mice, to evaluate the potential of the sDNA hydrogel as an intranasal delivery system to induce immunotherapeutic effects against allergic rhinitis.

\section{Materials and Methods}

Chemicals. RPMI 1640 medium was obtained from Nissui Pharmaceutical 
(Tokyo, Japan). Fetal bovine serum (FBS) was obtained from MP Biomedicals (Eschwege, Germany). Cryj1 was extracted from JCP by stirring in $0.125 \mathrm{M} \mathrm{NaHCO}_{3}$ solution ( $\mathrm{pH} 8.0$ ) for $1 \mathrm{~h}$ at room temperature, and the extract was purified by centrifugation at $15,000 \mathrm{~g}$ for $30 \mathrm{~min}$ and ultrafiltration of the supernatant using a $10-\mathrm{kDa}$ filter. The content of purified Cryj1 was determined by an ELISA kit for Cryj1 purchased from Nichinichi Pharmaceutical (Mie, Japan). Cryj1 was labeled with fluorescein isothiocyanate (FITC; fluorescein isothiocyanate isomer 1, Sigma-Aldrich, St. Louis, MO, USA) to obtain FITC-Cryj1. All other chemicals were of the highest grade available and used without further purification.

Cell culture. The murine macrophage-like cell line RAW264.7 was obtained from the American Type Culture Collection (Rockville, MD, USA). Cells were grown in RPMI 1640 medium supplemented with $10 \%$ heat-inactivated FBS, $0.15 \% \mathrm{NaHCO}_{3}$, 100 units $/ \mathrm{ml}$ penicillin, $100 \mu \mathrm{g} / \mathrm{ml}$ streptomycin, and $2 \mathrm{mM} \mathrm{L}$-glutamine at $37^{\circ} \mathrm{C}$ in humidified air containing $5 \% \mathrm{CO}_{2}$.

Animals. Male BALB/c mice (5 weeks old) were purchased from Japan SLC, Inc. (Shizuoka, Japan). Animals were maintained under conventional housing conditions. All animal experiments were approved by the Animal Experimentation Committee of the Graduate School of Pharmaceutical Sciences, Kyoto University.

Preparation of polypodna and DNA hydrogel loaded with Cryj1. All phosphodiester oligodeoxynucleotides (ODNs) were purchased from Integrated DNA Technologies, Inc. (Coralville, IA, USA). The hexapodna and DNA hydrogel was designed and prepared using the ODNs as reported in our previous study [14]. In brief, three immunostimulatory hexapodna (sHexa) with potent $\mathrm{CpG}$ motifs, and three non-immunostimulatory hexapodna (nsHexa) with no $\mathrm{CpG}$ motifs were prepared. sHexa-1 and sHexa-2 were designed to have complementary 5'-ends. nsHexa-1 and nsHexa-2 were also designed similarly. The sequence of sHexa-3 was identical to that of sHexa-2 except for their 5'-ends, and sHexa-3 did not have a 5'-end complementary to sHexa-1.

The formation of hexapodna was confirmed by $6 \%$ polyacrylamide gel electrophoresis (PAGE). Immunostimulatory and non-immunostimulatory DNA hydrogels (sDNA hydrogel and nsDNA hydrogel, respectively) were obtained by mixing equimolar amounts of sHexa-1 and sHexa- 2 or nsHexa-1 and nsHexa-2, respectively, at an initial concentration of 0.1 or $0.3 \mathrm{mM}$ DNA $(7 \mu \mathrm{g} / \mu 1 \mathrm{DNA}$ or 22 $\mu \mathrm{g} / \mu \mathrm{l}$ DNA, respectively). A hexapodna solution was also prepared as a control by mixing sHexa-1 and sHexa-3. To prepare the Cryj1-loaded DNA hydrogels (Cryj1/sDNA hydrogel and Cryj1/nsDNA hydrogel), Cryj1 was added to sHexa-1 and sHexa-2 or nsHexa-1 and nsHexa-2, respectively, before mixing. Hydrogel formation was briefly confirmed by adding a solution containing blue dextran (Sigma-Aldrich), which does not instantly diffuse into hydrogels, or by $6 \%$ PAGE as previously reported [14].

Observation of the inner structure of the sDNA hydrogel and Cryj1/sDNA hydrogel by scanning electron microscopy. The inner structures of the $0.1 \mathrm{mM}$ and $0.3 \mathrm{mM}$ Cryj $1 / \mathrm{sDNA}$ hydrogels were observed using a field-emission scanning electron microscope (FE-SEM: S4700; HITACHI, Japan) as previously described [14]. In brief, the samples were fixed with $2 \%$ glutaraldehyde at room temperature overnight, dehydrated with increasing concentrations of ethanol that was then replaced with butyl alcohol, and then freeze-dried. The dried material was cracked with a knife, and the inner structure of the DNA hydrogels was observed.

Cryj1 release from DNA hydrogel in vitro. FITC-Cryj1 was mixed with 
sHexa-1 and sHexa-2 solutions, and $0.1 \mathrm{mM}$ and $0.3 \mathrm{mM}$ sDNA hydrogels containing FITC-Cryj1 were prepared as described above. As a control, FITC-Cryj1 was mixed with sHexa-1 and sHexa-3 solutions, and $0.1 \mathrm{mM}$ or $0.3 \mathrm{mM}$ sHexa solution containing FITC-Cryj1 (FITC-Cryj1+sHexa) was prepared. Then, the FITC-Cryj1/sDNA hydrogel or FITC-Cryj1+sHexa was placed into the upper chamber of a Transwell (Product\#3460, $0.4-\mu \mathrm{m}$ pore size; Corning Inc., Corning, NY, USA), and $1000 \mu \mathrm{l}$ of PBS was added into the bottom chamber, followed by incubation at $37^{\circ} \mathrm{C}$. At predetermined time points, fluorescence images of FITC-Cryj1/sDNA hydrogel were obtained using LAS3000 system (Fujifilm, Tokyo, Japan), and the fluorescence intensity of the receiver solution was measured in a Wallac1420 ARVO MX-2 Multilabel Counter (Perkin-Elmer, Boston, MA, USA).

IL-12 release from RAW264.7 cells. RAW264.7 cells were plated on 24-well culture plates at a density of $5 \times 10^{5}$ cells $/ \mathrm{ml}\left(2.5 \times 10^{5}\right.$ cells/well $)$ and cultured for $24 \mathrm{~h}$ before use. ssODN (a mixture of CpG Hex.-1-1 and CpG Hex.-3-1), sHexa (a mixture of sHexa-1 and sHexa-3), sDNA hydrogel, nsDNA hydrogel, ssODN with Cryj1 (Cryj1+ssODN), sHexa with Cryj1 (Cryj1+sHexa), sDNA hydrogel or nsDNA hydrogel physically mixed with Cryj1 (Cryj1+sDNA hydrogel or Cryj1+nsDNA hydrogel, respectively), or Cryj1/sDNA hydrogel was diluted in Opti-MEM buffer (Life Technologies, Carlsbad, CA, USA) to a concentration of $100 \mu \mathrm{g} / \mathrm{ml}$ DNA and $20 \mu \mathrm{g} / \mathrm{ml}$ Cryj1, before it was added to the cells. The cells were incubated for $16 \mathrm{~h}$, and the supernatants were collected and stored at $-80^{\circ} \mathrm{C}$ until assayed. The level of IL-12p40 in the supernatant was determined by enzyme-linked immunosorbent assay (ELISA) by using an OptEIA ${ }^{\mathrm{TM}}$ set (BD Biosciences, San Diego, CA, USA).

Cellular uptake of FITC-Cryj1 by RAW264.7 cells. RAW264.7 cells were plated on 96 -well culture plates at a density of $5 \times 10^{5}$ cells $/ \mathrm{ml}\left(5 \times 10^{4}\right.$ cells/well $)$ and cultured for $24 \mathrm{~h}$ before use. The cells were then washed twice with $100 \mu \mathrm{l}$ of PBS and incubated with FITC-Cryj1, FITC-Cryj1 with ssODN (FITC-Cryj1+ssODN), FITC-Cryj1 with sHexa (FITC-Cryj1+sHexa), FITC-Cryj1 with sDNA hydrogel (FITC-Cryj1+sDNA hydrogel), or FITC-Cryj1/sDNA hydrogel at $37^{\circ} \mathrm{C}$ or $4^{\circ} \mathrm{C}$. At $3 \mathrm{~h}$ after addition, the cells were washed three times with $200 \mu \mathrm{l} \mathrm{PBS}$. Then, fluorescent intensity of the cells was determined by flow cytometry (FACSCalibur; BD Biosciences, San Jose, CA, USA) using CellQuest software (version 3.1; BD Biosciences), and the mean fluorescence intensity (MFI) was calculated as an indicator of the cellular uptake of FITC-Cryj1.

Distribution and clearance of Cryj1/DNA hydrogel after intranasal administration to mice. A mixed solution of sHexa and FITC-Cryj1 (FITC-Cryj1+sHexa) (50 $\mu$ g DNA, $10 \mu \mathrm{g}$ Cryj1/mouse) or FITC-Cryj1/sDNA hydrogel (50 $\mu \mathrm{g}$ DNA, $10 \mu \mathrm{g}$ Cryj1/mouse) was intranasally (i.n.) administered to BALB/c mice by using a micropipette, under anesthesia with pentobarbital at a concentration of 0.1 mM DNA. At 0.5, 3, and $6 \mathrm{~h}$ after administration, the mice were killed, and nasal lavage fluid (NFL) was collected by washing the nasal cavity with $800 \mu \mathrm{l}$ of PBS. The concentration of DNA in the NFL was measured at $260 \mathrm{~nm}$ by NanoDrop ${ }^{\text {TM }} 2000$ (Thermo Scientific, Waltham, MA, USA), and the concentration of Cryj1 was evaluated by measuring the fluorescence intensity of the samples in a Wallac1420 ARVO MX-2 Multilabel Counter. In different sets of mice, the distribution of DNA was observed using LAS3000 after staining of DNA remaining in the nasal cavity with SYBR Gold (Life Technologies, Carlsbad, CA, USA).

IL-12 production in serum and NFL after intranasal administration of the sDNA hydrogel to mice. Saline, ssODN, or sDNA hydrogel was administered i.n. to 
$\mathrm{BALB} / \mathrm{c}$ mice by using a micropipette at a dose of $50 \mu \mathrm{g}$ DNA/mouse (DNA concentration: $0.1 \mathrm{mM}, 6.8 \mu \mathrm{l} /$ mouse) under anesthesia with pentobarbital. At $6 \mathrm{~h}$ after administration, the mice were killed, and their blood was collected to obtain serum after centrifugation. NFL was also collected by washing the nasal cavity with $1000 \mu \mathrm{l}$ of PBS. The level of IL-12p40 in the serum and NFL was determined by ELISA.

IL-12 and IFN- $\gamma$ release from spleen cells after immunization of mice. Cryj1, Cryj1 and ssODN (Cryj1+ssODN), Cryj1 and sHexa (Cryj1+sHexa), or the Cryj1/sDNA hydrogel was administered i.n. to BALB/c mice at a dose of $50 \mu \mathrm{g}$ DNA and $10 \mu \mathrm{g}$ Cryj1/mouse (DNA concentration: $0.1 \mathrm{mM}$ ) under anesthesia with pentobarbital. A different set of mice received a subcutaneous (s.c.) injection of Cryj1 at a dose of $10 \mu \mathrm{g} / \mathrm{mouse}$ under anesthesia with isoflurane. The mice were immunized twice on days 0 and 14. At 14 days after the second immunization, the mice were killed and serum, spleen, and NFL were collected. Spleen cells were purified and cultured in the presence of Cryj1 $(2.5 \mu \mathrm{g} / \mathrm{ml})$ in 12-well culture plates for 3 days. The concentration of IL-12p40 in the supernatant was determined as described above. The concentration of IFN- $\gamma$ in the supernatant was determined by ELISA by using an Mouse IFN gamma ELISA Ready-SET-Go! (eBioscience, San Diego, CA, USA).

Cryj1-specific antibodies in serum and NFL of mice after immunization. The titers of Cryj1-specific IgG in serum and NFL were measured by ELISA. Briefly, ELISA plates were coated with Cryj1 in PBS overnight at $4^{\circ} \mathrm{C}(2.5 \mu \mathrm{g} / \mathrm{ml} \mathrm{Cry} \mathrm{j} 1)$. After coating, 1000-fold diluted serum samples and non-diluted NFL samples were added to the plates and incubated at $37^{\circ} \mathrm{C}$ for $2 \mathrm{~h}$. After washing, HRP-labeled anti-mouse $\mathrm{IgG}$ (Wako Pure Chemical, Osaka, Japan) was added, and the samples were incubated at $37^{\circ} \mathrm{C}$ for $1 \mathrm{~h}$. After additional washing, $o$-phenylenediamine substrate was added, and the OD was measured at $450 \mathrm{~nm}$. Anti-Cryj1 mouse monoclonal antibody (Funakoshi, Tokyo, Japan) was used as a standard for Cryj1-specific IgG.

IgE in serum of mice after nasal immunization. Cryj1, Cryj1 and ssODN (Cryj1+ssODN), Cryj1 and sHexa (Cryj1+sHexa), or the Cryj1/sDNA hydrogel was administered i.n. to BALB/c mice at a dose of $50 \mu \mathrm{g}$ DNA and $10 \mu \mathrm{g}$ Cryj1/mouse (DNA concentration: $0.1 \mathrm{mM}$ ) under anesthesia with pentobarbital. The mice were immunized three times on days 0,7 and 14 . At 14 days after the third immunization, the mice were killed and serum was collected. The concentration of IgE in serum was determined by ELISA using an OptEIA ${ }^{\mathrm{TM}}$ set (BD Biosciences).

Statistical analysis. Differences were statistically evaluated by one-way analysis of variance (ANOVA) followed by the Tukey-Kramer test for multiple comparisons and Student's $t$-test for two groups. $P<0.05$ was considered to be statistically significant. 


\section{Results}

Formation of Cryj1/sDNA hydrogel. Fig. 1 shows typical FE-SEM images of the inner structure of the sDNA hydrogel and Cryj1/sDNA hydrogel. The images indicate that the sDNA hydrogel has a highly ordered structure with plenty of space. The inner structure of Cryj1/sDNA hydrogel was thicker than that of sDNA hydrogel, suggesting that Cryj1 is uniformly bound to the DNA network. The structure of Cryj1/sDNA hydrogel became denser with an increasing DNA concentration.

sDNA hydrogel (0.3 mM DNA)

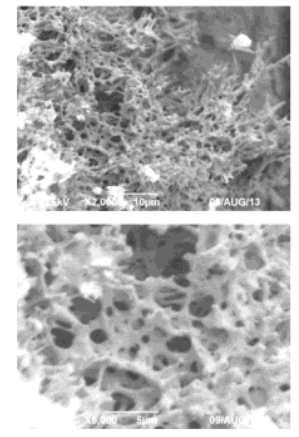

Cryj1/sDNA hydrogel (0.3 mM DNA)

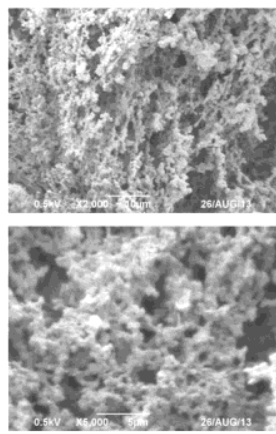

Cryj1/sDNA hydrogel (0.1 mM DNA)

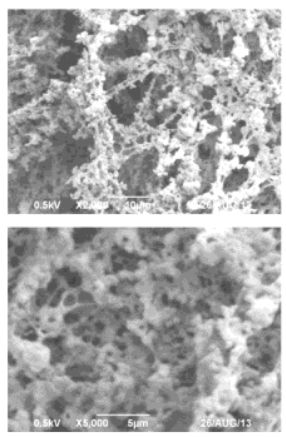

Fig. 1. FE-SEM images of the inner structure of sDNA hydrogel and Cryj1/sDNA hydrogel. Left, sDNA hydrogel (0.3 mM DNA); center, Cryj 1/sDNA hydrogel ( 0.3 mM DNA); right, Cryj1/sDNA hydrogel (0.1 mM DNA). Images were taken using a field-emission scanning electron microscope at low ( $\times 2000$, upper panels) and high $(\times 5000$, lower panels $)$ magnifications.

Sustained release of Cryj 1 from sDNA hydrogel. To visualize Cryj1 release, FITC-labeled Cryj1 was encapsulated into sDNA hydrogels prepared at a concentration of 0.1 or $0.3 \mathrm{mM}$ DNA. Fig. 2a shows fluorescence images of the FITC-Cryj1/sDNA hydrogel placed into the upper chamber of the Transwell. The images clearly show that FITC-Cryj 1 was slowly released from the sDNA hydrogel. When a $0.3 \mathrm{mM}$ sDNA hydrogel was applied, FITC-Cryj1 remained at the location where the hydrogel was placed for at least $1 \mathrm{~h}$. In contrast, FITC-Cryj 1 quickly diffused away soon after a 0.1 mM sDNA hydrogel was applied. These results suggest that the shape of the $0.3 \mathrm{mM}$ sDNA hydrogel was maintained longer than that of the $0.1 \mathrm{mM}$ sDNA hydrogel. No significant differences in the fluorescence images were observed between the two groups at $6 \mathrm{~h}$ or later. The fluorescence intensity of the solution in the lower chamber also showed that FITC-Cryj1 was gradually released from the sDNA hydrogel, whereas it was rapidly released from sHexa solution within $2 \mathrm{~h}$ (Fig. 2b). The initial release of Cryj1 from the $0.1 \mathrm{mM}$ sDNA hydrogel was faster than that from the $0.3 \mathrm{mM}$ sDNA hydrogel, but no significant difference between the $0.1 \mathrm{mM}$ and $0.3 \mathrm{mM}$ hydrogels was observed in the release profile at $6 \mathrm{~h}$ or later.

IL-12 release from RAW264.7 cells by the Cryj1/sDNA hydrogel. To investigate the effect of sDNA hydrogel formation and Cryj1 loading into the sDNA hydrogel on the production of an innate immune response, IL-12 release from RAW264.7 cells was examined after addition of a variety of components of the sDNA hydrogel with or without Cryj1. Fig. 3 shows the IL-12 concentrations in the supernatant of the RAW264.7 cells at $16 \mathrm{~h}$ after addition of Cryj1 $(20 \mu \mathrm{g} / \mathrm{ml})$, DNA $(100 \mu \mathrm{g} / \mathrm{ml})$ or their combination. The IL-12 secretion induced by the Cryj1/sDNA hydrogel was significantly greater $(P<0.05)$ than that induced by Cryj1+ssODN or Cryj1+sHexa. In addition, Cryj1+sHexa induced higher secretion of IL-12 than Cryj1+ssODN. The nsDNA hydrogel with no CpG motifs induced only low IL-12 secretion in the medium. There was no significant difference between sDNA hydrogel and Cryj1+sDNA hydrogel, suggesting that Cryj1 itself hardly has any effect on IL-12 induction. 
a

FITC-Cryj 1 /sDNA hydrogel (0.1 mM DNA)

$\mathrm{Oh}$

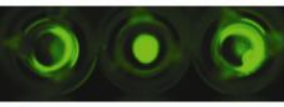

$1 \mathrm{~h}$

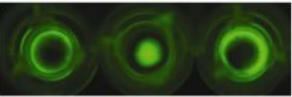

$3 \mathrm{~h}$

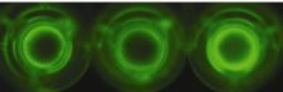

$6 \mathrm{~h}$

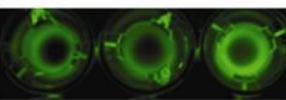

$12 \mathrm{~h}$

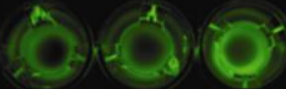

$24 \mathrm{~h}$

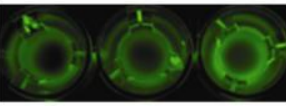

b
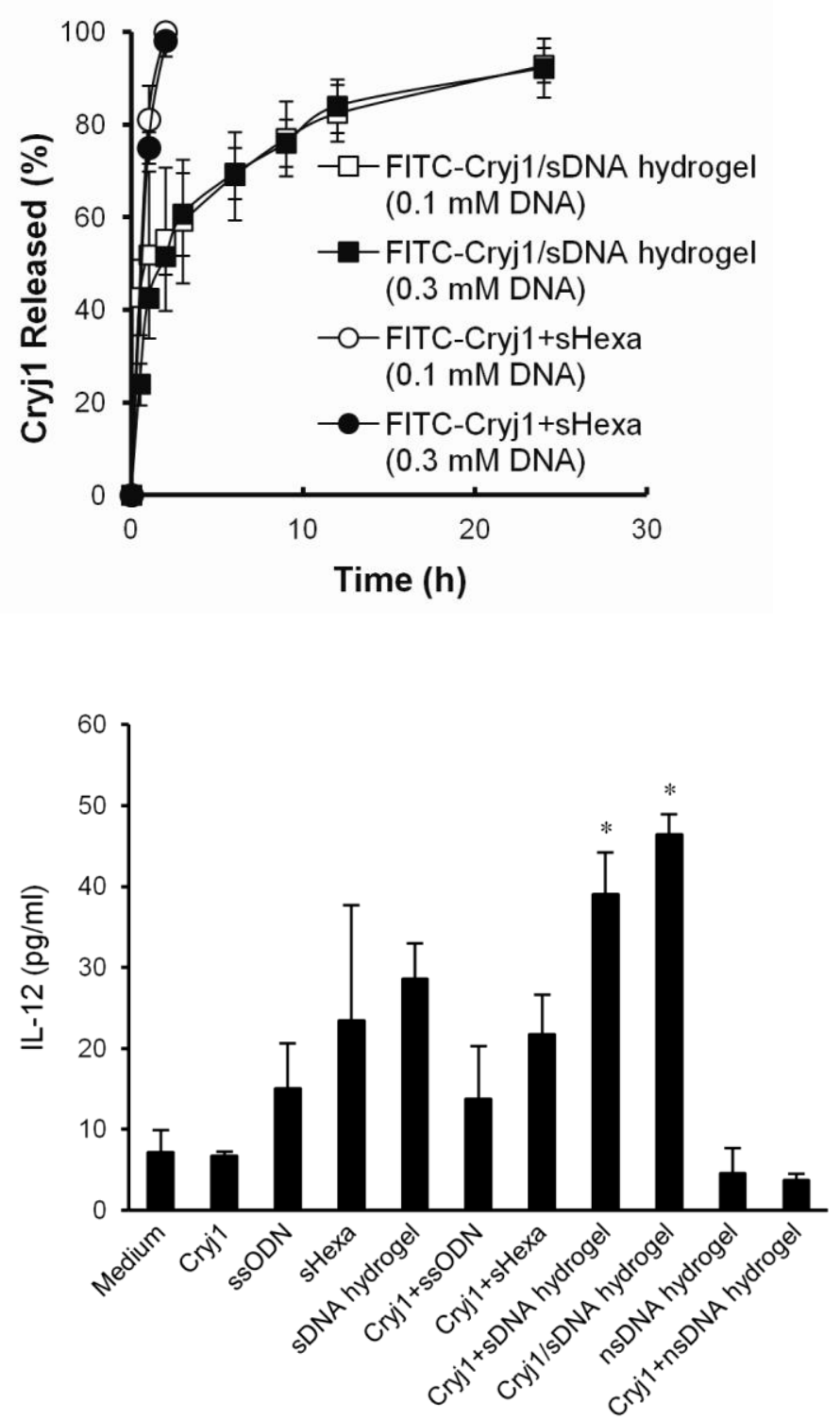

FITC-Cryj1 /sDNA hydrogel (0.3 mM DNA)
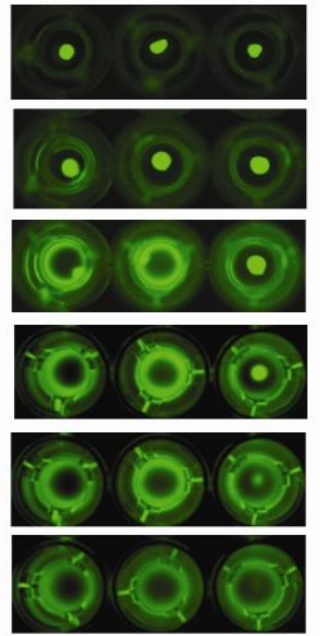

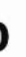

Fig. 3. IL-12 release from RAW264.7 cells after addition of Cryj1, ssODN, sHexa, sDNA hydrogel, nsDNA hydrogel, their mixture with Cryj 1, and the Cryj1/sDNA hydrogel at a ratio of $20 \mu \mathrm{g}$ Cryj1/100 $\mu \mathrm{g}$ DNA. IL-12 in the supernatant was measured after $16 \mathrm{~h}$ of incubation with each component. Results are expressed as mean \pm $\mathrm{SD}$ of three determinations. $* \mathrm{P}<$ 0.05 , significantly different from the Cryj1+ssODN group. 
Cellular uptake of FITC-Cryj1 by RAW264.7 cells. Fig. 4 shows the mean fluorescence intensity (MFI) of RAW264.7 cells incubated at $37^{\circ} \mathrm{C}$ after addition of FITC-Cryj1, FITC-Cryj1+ssODN, FITC-Cryj1+sHexa, FITC-Cryj1+sDNA hydrogel, or FITC-Cryj1/sDNA hydrogel. The MFI of cells incubated with the FITC-Cryj1/sDNA hydrogel was significantly greater $(\mathrm{P}<0.05)$ than that incubated with any other samples examined, suggesting that FITC-Cryj1 loading into sDNA hydrogel increase cellular uptake of FITC-Cryj1.

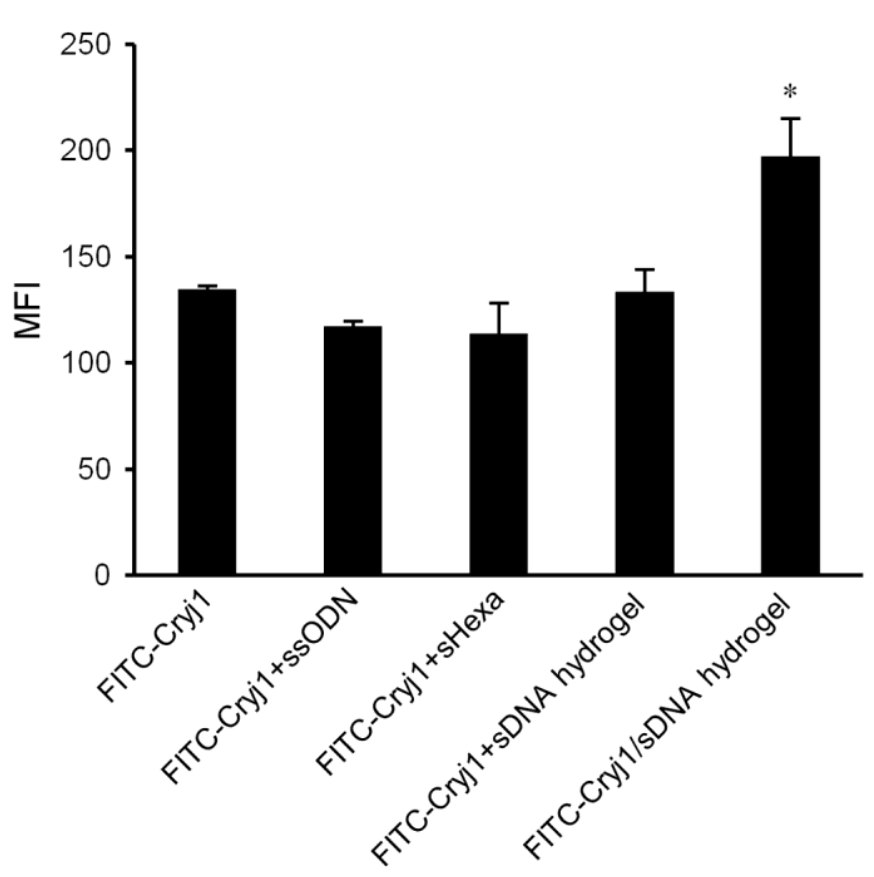

Fig. 4. Uptake of FITC-Cryj1 by RAW 264.7 cells. RAW264.7 cells were incubated at $37^{\circ} \mathrm{C}$ for $3 \mathrm{~h}$ with FITC-Cryj1, FITC-Cryj1+ssODN, FITC-Cryj1+sHexa, FITC-Cryj1+sDNA hydrogel, or FITC-Cryj1/sDNA hydrogel at concentrations of $20 \mu \mathrm{g} / \mathrm{ml}$ FITC-Cryj 1 and $100 \mu \mathrm{g} / \mathrm{ml}$ DNA. The amounts of FITC-Cryj1 associated with cells were measured by flow cytometry. Results are expressed as mean \pm $\mathrm{SD}$ of four determinations. $* \mathrm{P}<$ 0.05 , significantly different from all other groups.

Distribution and clearance of FITC-Cryj1/sDNA hydrogel after intranasal administration to mice. Fig. 5 shows the amount of FITC-Cryj1 and DNA remaining in the nasal cavity after intranasal administration of FITC-Cryj1+sHexa or the FITC-Cryj1/sDNA hydrogel. In both cases, FITC-Cryj1 and DNA showed similar elimination profiles. The half-life of FITC-Cryj1 and DNA in the nasal cavity was approximately 3-4 $\mathrm{h}$ after administration of the FITC-Cryj1/sDNA hydrogel, whereas it was approximately $0.5 \mathrm{~h}$ after administration of FITC-Cryj $1+$ sHexa. Fig. 5b shows fluorescence images of mouse heads after intranasal administration of Cryj1+sHexa or the Cryj1/sDNA hydrogel. To visualize DNA, the sHexa and sDNA hydrogel remaining in the cavity were stained with SYBR Gold. This imaging also showed that the sDNA hydrogel remained in the nasal cavity for a longer period of time than sHexa.

\section{IL-12 production after intranasal administration of SDNA hydrogel to mice} Fig. 6 shows the concentration of IL-12 in the serum and NFL at $6 \mathrm{~h}$ after intranasal administration of saline, ssODN or the sDNA hydrogel at a dose of $50 \mu \mathrm{g} / \mathrm{mouse}$. The level of IL-12 in the serum after administration of sDNA hydrogel was significantly $(P<0.05)$ greater than that after administration of ssODN, and a similar trend was observed in the IL-12 level of the NFL. These results suggest that hydrogel formation increases the potency of $\mathrm{CpG}$ DNA to induce systemic and mucosal Th1 immune responses. 
a

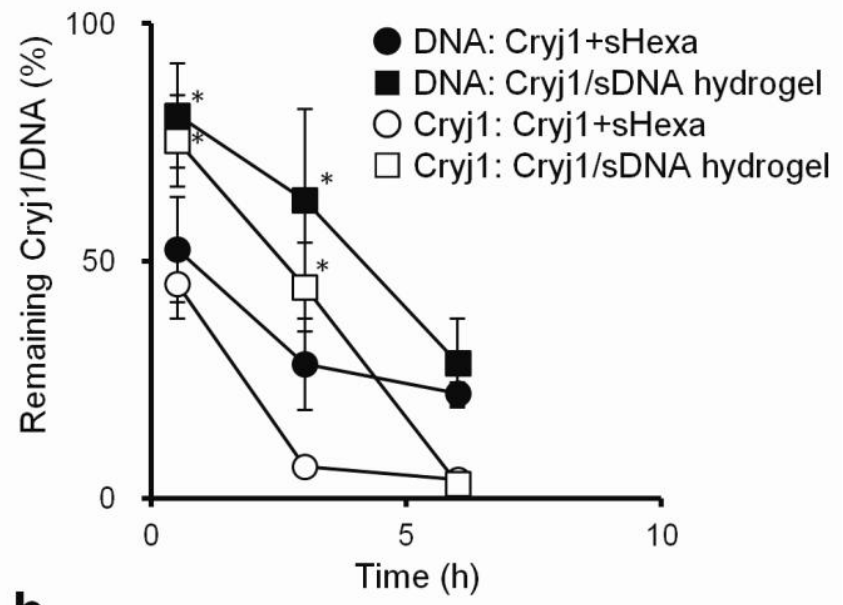

b
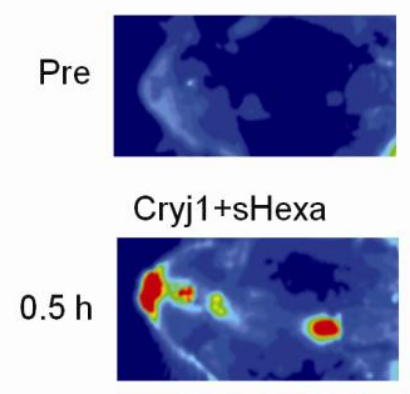

Cryj1/sDNA hydrogel

$3 \mathrm{~h}$
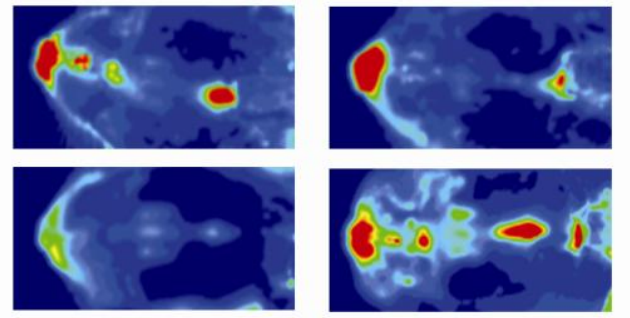

$6 \mathrm{~h}$
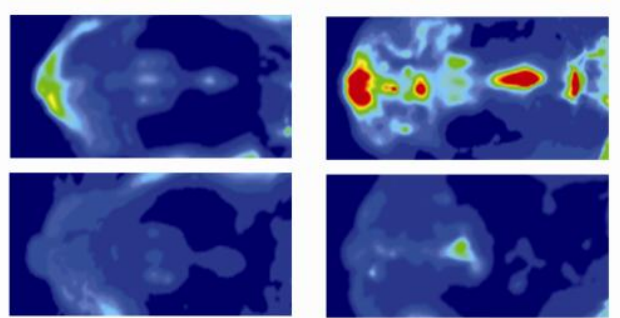

Fig.5. Distribution and clearance of FITC-Cryj1/sDNA hydrogel in nasal cavity after nasal administration into mice. (a) FITC-Cryj1+sHexa or FTIC-Cryj1/sDNA hydrogel $(50 \mu \mathrm{g}$ DNA, $10 \mu \mathrm{g}$ Cryj1/mouse) was intranasally administrated. NFL was collected at the indicated time, and the concentration of DNA and Cryj1 from FITC-Cryj1+sHexa or the FITC-Cryj1/sDNA hydrogel was measured and plotted against time.

Results are expressed as mean \pm SD of three determinations. $* \mathrm{P}<0.05$, significantly different from the Cryj1+sHexa group. (b) Cryj1+sHexa (left) or the Cryj1/sDNA hydrogel (right) was intranasally administered after staining of DNA with SYBR Gold $(50 \mu \mathrm{g}$ DNA, $10 \mu \mathrm{g}$ Cryj1/mouse). Mice were killed at the indicated time and dissected. Then, fluorescence distribution around the nasal mucosa was photographed. As a control, the fluorescence distribution before administration was also photographed (Pre, top). 


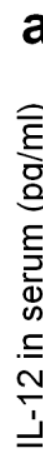

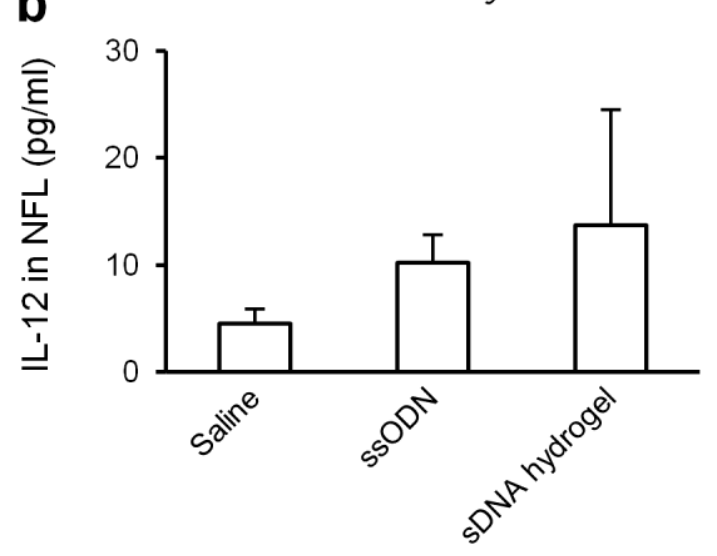

Fig.6. IL-12 production after intranasal administration of the sDNA hydrogel to mice. Saline, ssODN, or the sDNA hydrogel was administrated intranasally to mice ( $50 \mu \mathrm{g} / \mathrm{mouse})$. At $6 \mathrm{~h}$ after injection, serum and NFL were collected to measure the level of IL-12. (a) IL-12 concentration in serum. (b) IL-12 concentration in NFL. Results are expressed as the mean \pm SD of five determinations. $* \mathrm{P}<0.05$, significantly different from the ssODN alone group.

\section{Induction of immune response to Cryj1 by intranasal administration of} Cryj1/sDNA hydrogel. To investigate the effects of CpG DNA formulation, Cryj1 loading into the hydrogel, and administration route on the inhibition of allergic reactions, the Cryj1-specific Th1 immune response and Cryj1-specific antibody levels after immunization were evaluated. Fig. 7a shows the concentration of IL-12 in the supernatant of spleen cells after re-stimulation with Cryj 1 for $72 \mathrm{~h}$. The spleen cells from mice immunized with intranasal Cryj1/sDNA hydrogel produced significantly $(P<0.05)$ more IL-12 than those from mice treated with subcutaneous Cryj1, intranasal Cryj1, or intranasal Cryj1+ssODN. Fig. 7b shows the concentration of IFN- $\gamma$ in the supernatant of spleen cells after re-stimulation with Cryj 1 for $72 \mathrm{~h}$. The spleen cells from mice immunized with intranasal Cryj1/sDNA hydrogel produced significantly $(P<0.05)$ more IFN $-\gamma$ than those from mice treated with intranasal Cryj1, or intranasal Cryj1+ssODN. No significant difference in IL-12 and IFN- $\gamma$ secretion from re-stimulated spleen cells was observed among the different administration routes of Cryj1.

Intranasal immunization with the Cryj1/sDNA hydrogel induced a higher level of Cryj1-specific IgG in the serum and a higher level of Cryj1-specific IgG in the NFL compared with intranasal immunization with Cryj1, Cryj1+ssODN, or Cryj1+sHexa (Fig. 7c, d). Intranasal immunization with Cryj1/sDNA hydrogel induced a higher level of Cryj1-specific IgG in NFL and almost the same level of Cryj1-specific IgG in serum compared with subcutaneous immunization with Cryj1 (Fig. 7c, d). 

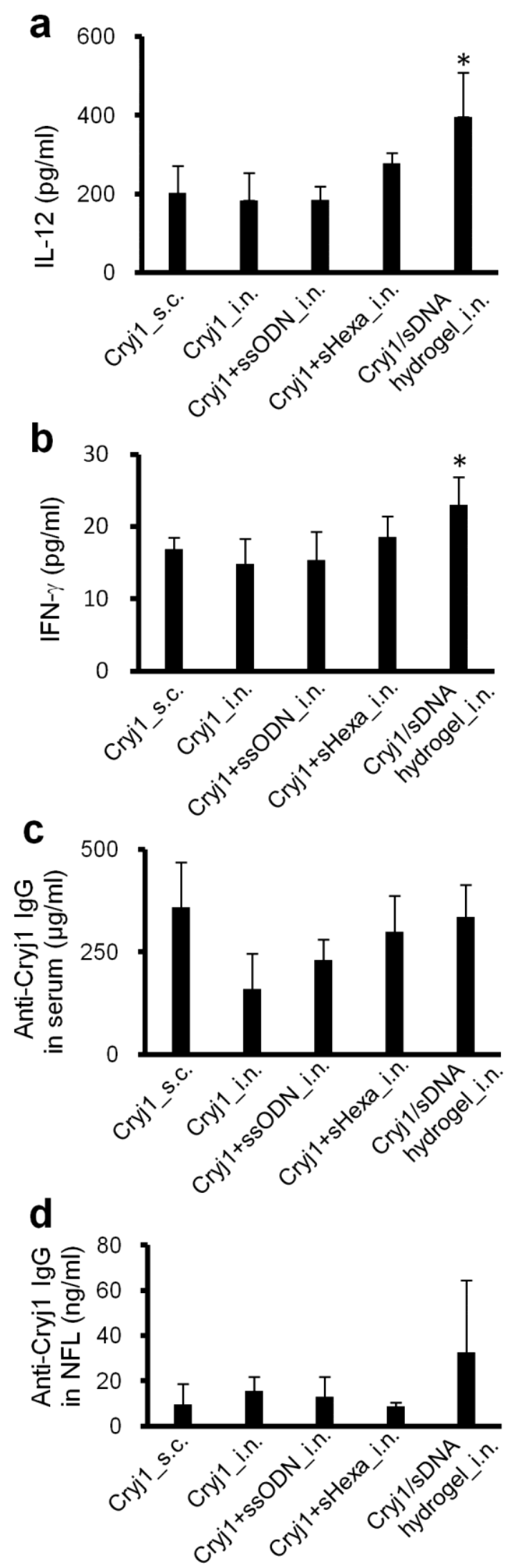

Fig. 7. Induction of Cryj1-specific immune reactions by intranasal administration of Cryj1/sDNA hydrogel. Mice were immunized on day 0 and 14 with Cryj1subcutaneously (s.c.), Cryj1 intranasally (i.n.), Cryj1+ssODN i.n., Cryj1+sHexa i.n. or Cryj1/sDNA hydrogel i.n. (50 $\mu \mathrm{g}$ DNA, $10 \mu \mathrm{g}$ Cryj1/mouse). At 14 days after the last immunization, spleen cells, serum, and NFL were collected. (a) Concentration of IL-12 in the supernatant of spleen cells at $72 \mathrm{~h}$ after re-stimulation with Cryj1. (b) Concentration of IFN- $\gamma$ in the supernatant of spleen cells at $72 \mathrm{~h}$ after re-stimulation with Cryj1. (c) Concentration of Cryj1-specific IgG in serum. (d) Concentration of Cryj1-specific IgG in NFL. ${ }^{*} \mathrm{P}<0.05$, significantly different from the Cryj1 only group and Cryj1+ssODN i.n. group. 


\section{Suppression of Th2 response by intranasal administration of Cryj1/sDNA}

hydrogel. To investigate the effects of the Cryj1 loading into the sDNA hydrogel on the inhibition of allergic sensitivity, serum IgE levels after immunization were evaluated as a Th2 response indicator. Fig. 8 shows the concentration of IgE in the serum after immunization. The serum IgE level of mice immunized with Cryj1/sDNA hydrogel was significantly lower $(P<0.05)$ than that of mice immunized with Cryj1, suggesting that loading of Cryj1 into sDNA hydrogel could attenuate Th2 response, and suppress allergic reactions.

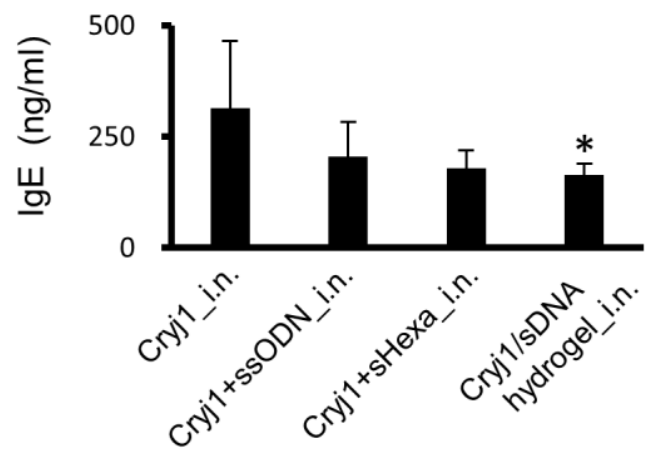

Fig. 8. Supression of Th2 response by intranasal administration of Cryj1/sDNA hydrogel. Mice were immunized on days 0, 7 and 14 with Cryj1 intranasally (i.n.), Cryj1+ssODN i.n., Cryj1+sHexa i.n. or Cryj1/sDNA hydrogel i.n. (50 $\mu \mathrm{g}$ DNA, 10 $\mu \mathrm{g}$ Cryj1/mouse). At 14 days after the last immunization, serum was collected, and the concentration of $\operatorname{IgE}$ in serum was measured. Results are expressed as mean \pm SD of six determinations. *P $<0.05$, significantly different from the Cryj1 only group. 


\section{Discussion}

Understanding of the mechanisms underlying pollen-induced allergic rhinitis has led to the development of vaccines against allergies [19]. Although subcutaneous injection of allergens has traditionally been the main immunotherapy method, several other formulations including sublingual solutions of JCP extracts and sublingual tablets containing grass pollen extracts have been approved in the US, Japan, and other countries [18]. In addition, local intranasal delivery of allergens is another promising method for administration, and several clinical trials have been conducted worldwide [20]. Intranasal immunotherapy could be convenient and ensure patient compliance, although current formulations would induce an insufficient immune response because of rapid clearance and inefficient uptake of the allergen by nasal immune cells [21]. Thus far, CpG DNA has been applied in the intranasal delivery of allergens as an adjuvant for allergic rhinitis immunotherapy to induce an efficient immune response [22], but no attempts have been made to use CpG DNA as a component for a controlled release formation of allergens. Therefore, we examined in this study whether an injectable DNA hydrogel consisting of CpG DNA that we previously developed is useful for intranasal delivery of Cryj1, the typical allergen of JCP.

As demonstrated in our previous study using ovalbumin as a cargo [14], Cryj1 was slowly released from the DNA hydrogel not only under in vitro conditions but also in the nasal cavity of mice (Figs. 2, 5). Because sustained release of antigens is well known to effectively induce antigen-specific immune responses [23-24], this slow release of Cryj1 from sDNA hydrogel should result in the induction of a high level of Cryj1-specific immune responses (Fig. 7).

One of our unique findings for nanostructured $\mathrm{CpG}$ DNA is that the immunostimulatory activity of CpG DNA is dependent on the structural complexity of the DNA, which should be at least partly related to increased cellular uptake of $\mathrm{CpG}$ DNA [13, 25-26]. The higher activity of the sDNA hydrogel, which consists of two sets of hexapodna, compared to sHexa (Figs. 3, 6) clearly indicates that multiple units of hexapodna would be efficiently taken by cells and recognized by the immune cells when the sDNA hydrogel is used. Efficient cellular uptake of DNA hydrogel is supposed to result in increased uptake of Cryj1 when added to RAW264.7 cells as Cryj1/sDNA hydrogel (Fig. 4). The importance of the immunostimulatory $\mathrm{CpG}$ motif in the immune responses was also confirmed by the IL-12 release from RAW264.7 cells (Fig. 3), which was comparable with the previous results for a DNA hydrogel containing OVA [14]. Therefore, the efficient induction of Cryj1-sepcific immune response by the Cryj1/sDNA hydrogel (Fig. 7) and the suppression of Th2 response (Fig. 8) results from (1) the sustained release of Cryj1 from the hydrogel and (2) the high immunostimulatory activity of the sDNA hydrogel relative to sHexa. Cryj1-specific IgG after intranasal immunization (Fig. 7c, d) did not show significant differences among the groups, although it tended to increase by loading Cryj into sDNA hydrogel. This could be explained by considering that the immunization increased only some $\operatorname{IgG}$ subtypes.

Nasal sprays are a patient-friendly device for drug administration to the nasal cavity. To increase the retention of pharmaceutical agents within the cavity, hydrogels are used for the intranasal delivery. Although this approach is promising, the administration of hydrogels is not suitable for the spread of the sprayed materials within the cavity [27]. Substrates that form gels upon changes in environmental factors, such as temperature changes, would solve this problem [28]. In the present study, we administered a DNA hydrogel prepared in vitro prior to administration to mice. 
However, the self-gelling property of the DNA hydrogel enables us to deliver the components, i.e., hexapodna in the present case, as a solution and then to obtain the DNA hydrogel by spontaneous hybridization of the components within the nasal cavity. This property will be beneficial for DNA hydrogels prepared using self-gelling nucleic acids. 


\section{Conclusion}

The present study demonstrated that a CpG motif-containing sDNA hydrogel loaded with Cryj1 is useful to induce effective immune responses specific to Cryj1 by intranasal administration. Our results also indicate that the sustained release of Cryj1 from the sDNA hydrogel and the efficient immune stimulation by the sDNA hydrogel are the major two factors underlying the Cryj1-specific immune responses. These findings introduce the application of DNA hydrogels as a mucosal delivery system for shorter immunotherapy with a lower burden.

\section{Acknowledgements}

This work is supported in part by Grants-in-Aid for Scientific Research (B) (23390010 and 26293008 to M.N., and 26293368 to S.F.) from the Japan Society for the Promotion of Science, by a Grant-in-Aid for Scientific Research on Innovative Areas "Carcinogenic spiral" (25114706 to M.N.) from the Ministry of Education, Culture, Sports, Science and Technology of Japan.

\section{References}

[1] Klinman DM, Yi AK, Beaucage SL, Conover J, Krieg AM. CpG motifs present in bacteria DNA rapidly induce lymphocytes to secrete interleukin 6, interleukin 12, and interferon $\gamma$. Proc Natl Acad Sci USA 1996;93:2879-83.

[2] Sparwasser T, Miethke T, Lipford G, Erdmann A, Häcker H, Heeg K, Wagner H. Macrophages sense pathogens via DNA motifs: induction of tumor necrosis factor- $\alpha$-mediated shock. Eur J Immunol 1997;27:1671-9.

[3] Kumagai Y, Takeuchi O, Akira S. TLR9 as a key receptor for the recognition of DNA. Adv Drug Deliv Rev 2008;60:795-804.

[4] Vollmer J, Krieg AM. Immunotherapeutic applications of CpG oligodeoxynucleotide TLR9 agonists. Adv Drug Deliv Rev 2009;61:195-204

[5] Fonseca DE, Kline JN. Use of CpG oligonucleotides in treatment of asthma and allergic disease. Adv Drug Deliv Rev 2009;61:256-262

[6] Viswanathan RK, Busse WW. Allergen Immunotherapy in Allergic Respiratory Diseases. CHEST 2012;141:1303-14

[7] Scadding G, Durham SR. Mechanisms of sublingual immunotherapy. Immunol Allergy Clin North Am 2011;31:191-209.

[8] Creticos PS, Schroeder JT, Hamilton RG, Balcer-Whaley SL, Khattignavong AP, Lindblad R, Li H, Coffman R, Seyfert V, Eiden JJ, Broide D, the Immune Tolerance Network Group. Immunotherapy with a Ragweed-Toll-Like Receptor 9 Agonist Vaccine for Allergic Rhinitis. N Engl J Med 2006;355:1445-55.

[9] Tulic MK, Fiset PO, Christodoulopoulos P, Vaillancourt P, Desrosiers M, Lavigne F, Eiden J, Hamid Q. Amb a 1-immunostimulatory oligodeoxynucleotide conjugate immunotherapy decreases the nasal inflammatory response. J Allergy Clin Immunol 2004;113:235-41.

[10] Krieg AM. Therapeutic potential of Toll-like receptor 9 activation. Nat Rev Drug Discov 2006;5:471-84.

[11] Um SH, Lee JB, Park N, Kwon SY, Umbach CC, Luo D. Enzyme-catalysed assembly of DNA hydrogel. Nat Mater 2006;5:797-801.

[12] Mizuno Y, Naoi T, Nishikawa M, Rattanakiat S, Hamaguchi N, Hashida M, Takakura Y. Simultaneous delivery of doxorubicin and immunostimulatory $\mathrm{CpG}$ motif to tumors using a plasmid DNA/doxorubicin complex in mice. J Control Release 2010;141:252-9. 
[13] Nishikawa M, Mizuno Y, Mohri K, Matsuoka N, Rattanakiat S, Takahashi Y, Funabashi H, Luo D, Takakura Y. Biodegradable CpG DNA hydrogels for sustained delivery of doxorubicin and immunostimulatory signals in tumor-bearing mice. Biomaterials 2011;32:488-94

[14] Nishikawa M, Ogawa K, Umeki Y, Mohri K, Kawasaki Y, Watanabe H, Takahashi N, Kusuki E, Takahashi R, Takahashi Y, Takakura Y. Injectable, self-gelling, biodegradable, and immunomodulatory DNA hydrogel for antigen delivery, $\mathbf{J}$ Control Release 2014;180:25-32

[15] Brożek JL, Bousquet J, Baena-Cagnani CE, Bonini S, Canonica GW, Casale TB, van Wijk RG, Ohta K, Zuberbier T, Schünemann HJ, Allergic Rhinitis and its Impact on Asthma (ARIA) guidelines: 2010 Revision. J Allergy Clin Immunol 2010;126:466-76

[16] Sakashita M, Hirota T, Harada M, Nakamichi R, Tsunoda T, Osawa Y, Kojima A, Okamoto M, Suzuki D, Kubo S, Imoto Y, Nakamura Y, Tamari M, Fujieda S. Prevalence of allergic rhinitis and sensitization to common aeroallergens in a Japanese population, Int Arch Allergy Immunol 2010;151:255-61.

[17] Yamada T, Saito H, Fujieda S. Present state of Japanese cedar pollinosis: the national affliction. J Allergy Clin Immunol 2014;133:632-9.e5

[18] Tse MT. Oral immunotherapy approved. Nature Biotechnology 2014;32 405

[19] De Souza Rebouças J,1 Esparza I, Ferrer M, Sanz ML, Irache JM, Gamazo C. Nanoparticulate Adjuvants and Delivery Systems for Allergen Immunotherapy. J Biomed Biotechnol 2012;474605

[20] Passalacqua G, Canonica GW. Local nasal specific immunotherapy for allergic rhinitis. Allergy Asthma Clin Immunol. 2006;15:117-23

[21] Zaman M, Chandrudu S, Toth I. Strategies for intranasal delivery of vaccines. Drug Deliv. and Transl. Res. 2013;3:100-9.

[22] Suzuki M, Matsumoto T, Ohta N, Min WP, Murakami S. Intranasal CpG DNA therapy during allergen exposure in allergic rhinitis. Otolaryngology-Head and Neck Surgey 2007;136:246-51

[23] Petrovsky N, Aguilar JC. Vaccine adjuvants: Current state and future trends. Immunol and Cell Biology 2004;82:488-96.

[24] Nochi T, Yuki Y, Takahashi H, Sawada S, Mejima M, Kohda T, Harada N, Kong IG, Sato A, Kataoka N, Tokuhara D, Kurokawa S, Takahashi Y, Tsukada H, Kozaki S, Akiyoshi K, Kiyono H. Nanogel antigenic protein-delivery system for adjuvant-free intranasal vaccines. Nature Materials 2010;9, 572-8.

[25] Nishikawa M, Matono M, Rattanakiat S, Matsuoka N, Takakura Y. Enhanced immunostimulatory activity of oligodeoxynucleotides by Y-shape formation. Immunology 2008;124:247-55.

[26] Rattanakiat S, Nishikawa M, Funabashi H, Luo D, Takakura Y. The assembly of a short linear natural cytosine-phosphate-guanine DNA into dendritic structures and its effect on immunostimulatory activity. Biomaterials 2009;30:5701-6.

[27] Nazar H, Roldo M, Fatouros DG, van der Merwe SM, Tsibouklis J. Hydrogels in Mucosal Delivery. Therapeutic Delivery 2012;3: 535-55

[28] Nazar H, Fatouros DG, van der Merwe SM, Bouropoulos N, Avgouropoulos G, Tsibouklis J, Roldo M. Thermosensitive hydrogels for nasal drug delivery: The formulation and characterisation of systems based on $\mathrm{N}$-trimethyl chitosan chloride, Eur J Pharm Biopharm 2011;77:225-32. 


\section{Figure legends}

Fig.1. FE-SEM images of the inner structure of sDNA hydrogel and Cryj1/sDNA hydrogel. Left, sDNA hydrogel (0.3 mM DNA); center, Cryj1/sDNA hydrogel (0.3 mM DNA); right, Cryj1/sDNA hydrogel (0.1 mM DNA). Images were taken using a field-emission scanning electron microscope at low $(\times 2000$, upper panels $)$ and high $(\times 5000$, lower panels $)$ magnifications.

Fig. 2. Cryj 1 release from sDNA hydrogel. FITC-Cryj1 was loaded into the sDNA hydrogel or mixed with sHexa solution at a ratio of $1 \mu \mathrm{g}$ Cryj1/5 $\mu \mathrm{g}$ DNA, and then placed into the upper chamber of the Transwell $(0.4-\mu \mathrm{m}$ pore size $)$ with the bottom chamber containing PBS, followed by incubation at $37^{\circ} \mathrm{C}$. (a) The fluorescence images of the FITC-Cryj1/sDNA hydrogel prepared at DNA concentrations of $0.1 \mathrm{mM}$ (left) and $0.3 \mathrm{mM}$ (right) were photographed at the indicated times. (b) The concentration of FITC-Cryj1 released from $0.1 \mathrm{mM}$ or $0.3 \mathrm{mM}$ sDNA hydrogel and 0.1 or $0.3 \mathrm{mM}$ sHexa solution was measured and plotted against time.

Fig.3. IL-12 release from RAW264.7 cells after addition of Cryj1, ssODN, sHexa, sDNA hydrogel, nsDNA hydrogel, their mixture with Cryj1, and Cryj1/sDNA hydrogel at a ratio of $20 \mu \mathrm{g}$ Cryj $1 / 100 \mu \mathrm{g}$ DNA. IL-12 in the supernatant was measured after $16 \mathrm{~h}$ of incubation with each component. Results are expressed as mean \pm SD of three determinations. $* \mathrm{P}<0.05$, significantly different from the Cryj $1+$ ssODN group.

Fig. 4. Uptake of FITC-Cryj1 by RAW 264.7 cells. RAW264.7 cells were incubated at $37^{\circ} \mathrm{C}$ for $3 \mathrm{~h}$ with FITC-Cryj1, FITC-Cryj1+ssODN, FITC-Cryj1+sHexa, FITC-Cryj1+sDNA hydrogel, or FITC-Cryj1/sDNA hydrogel at concentrations of $20 \mu \mathrm{g} / \mathrm{ml}$ FITC-Cryj 1 and $100 \mu \mathrm{g} / \mathrm{ml}$ DNA. The amounts of FITC-Cryj1 associated with cells were measured by flow cytometry. Results are expressed as mean \pm SD of four determinations. $* \mathrm{P}<0.05$, significantly different from all other groups.

Fig. 5. Distribution and clearance of FITC-Cryj1/sDNA hydrogel in nasal cavity after nasal administration into mice. (a) FITC-Cryj1+sHexa or FTIC-Cryj1/sDNA hydrogel (50 $\mu \mathrm{g}$ DNA, $10 \mu \mathrm{g}$ Cryj1/mouse) was intranasally administrated. NFL was collected at the indicated time, and the concentration of DNA and Cryj1 from FITC-Cryj1+sHexa or the FITC-Cryj1/sDNA hydrogel was measured and plotted against time. Results are expressed as mean $\pm \mathrm{SD}$ of three determinations. $* \mathrm{P}<0.05$, significantly different from the Cryj1+sHexa group. (b) Cryj1+sHexa (left) or the Cryj1/sDNA hydrogel (right) was intranasally administered after staining of DNA with SYBR Gold (50 $\mu \mathrm{g}$ DNA, $10 \mu \mathrm{g}$ Cryj1/mouse). Mice were killed at the indicated time and dissected. Then, fluorescence distribution around the nasal mucosa was photographed. As a control, the fluorescence distribution before administration was also photographed (Pre, top).

Fig. 6. IL-12 production after intranasal administration of the sDNA hydrogel to mice. Saline, ssODN, or the sDNA hydrogel was administrated intranasally to mice $(50 \mu \mathrm{g} / \mathrm{mouse})$. At 6 $\mathrm{h}$ after injection, serum and NFL were collected to measure the level of IL-12. (a) IL-12 concentration in serum. (b) IL-12 concentration in NFL. Results are expressed as the mean \pm SD of five determinations. ${ }^{*} \mathrm{P}<0.05$, significantly different from the ssODN alone group.

Fig. 7. Induction of Cryj1-specific immune reactions by intranasal administration of Cryj1/sDNA hydrogel. Mice were immunized on day 0 and 14 with Cryj1subcutaneously (s.c.), Cryj1 intranasally (i.n.), Cryj1+ssODN i.n., Cryj1+sHexa i.n. or Cryj1/sDNA hydrogel i.n. (50 $\mu \mathrm{g}$ DNA, $10 \mu \mathrm{g}$ Cryj1/mouse). At 14 days after the last immunization, spleen cells, serum, and NFL were collected. (a) Concentration of IL-12 in the supernatant of spleen cells at $72 \mathrm{~h}$ after re-stimulation with Cryj1. (b) Concentration of IFN- $\gamma$ in the supernatant of spleen cells at $72 \mathrm{~h}$ after re-stimulation with Cryj1. (c) Concentration of Cryj1-specific IgG in serum. (d) Concentration of Cryj1-specific IgG in NFL. ${ }^{*} \mathrm{P}<0.05$, significantly different from the Cryj 1 only group and Cryj $1+$ ssODN i.n. group. ${ }^{\#} \mathrm{P}<0.05$, significantly different from all other groups. 
Fig. 8. Supression of Th2 response by intranasal administration of Cryj1/sDNA hydrogel. Mice were immunized on days 0,7 and 14 with Cryj 1 intranasally (i.n.), Cryj1+ssODN i.n., Cryj1+sHexa i.n. or Cryj1/sDNA hydrogel i.n. (50 $\mu \mathrm{g}$ DNA, $10 \mu \mathrm{g}$ Cryj1/mouse). At 14 days after the last immunization, serum was collected, and the concentration of $\operatorname{IgE}$ in serum was measured. Results are expressed as mean $\pm \mathrm{SD}$ of six determinations. ${ }^{*} \mathrm{P}<0.05$, significantly different from the Cryj 1 only group. 